University of Pennsylvania Carey Law School

Penn Law: Legal Scholarship Repository

Faculty Scholarship at Penn Law

2-14-2011

\title{
The Shifting Terrain of Risk and Uncertainty on the Liability Insurance Field
}

Tom Baker

University of Pennsylvania Carey Law School

Follow this and additional works at: https://scholarship.law.upenn.edu/faculty_scholarship

Part of the Health Economics Commons, Insurance Commons, Insurance Law Commons, Law and Economics Commons, Law and Society Commons, Other Sociology Commons, Risk Analysis Commons, and the Torts Commons

\section{Repository Citation}

Baker, Tom, "The Shifting Terrain of Risk and Uncertainty on the Liability Insurance Field" (2011). Faculty Scholarship at Penn Law. 336.

https://scholarship.law.upenn.edu/faculty_scholarship/336

This Article is brought to you for free and open access by Penn Law: Legal Scholarship Repository. It has been accepted for inclusion in Faculty Scholarship at Penn Law by an authorized administrator of Penn Law: Legal Scholarship Repository. For more information, please contact PennlawIR@law.upenn.edu. 


\title{
THE SHIFTING TERRAIN OF RISK AND UNCERTAINTY ON THE LIABILITY INSURANCE FIELD
}

\author{
Tom Baker:
}

[A] high degree of scientific and technical uncertainty permeates
the insurance industry, the very husiness that is charged with trans-
forming uncertainty into risk. . . Scrutiny of how insurers face their
own incapacities reveals that theirs is an uncertain business. and
that we live not so much in a risk society as in an uncertain society.

\section{INTROIJITIION}

Concepts can impede understanding. sometimes by persuading us that we understand something that we really do not: other times they impede understanding by diverting our attention from what we would readily recognize that we do not understand, if only we thought long enough about it. The conceptual link between insurance and riskwith risk understood here as the calculable subset within a larger set of uncertainties-may be one such impediment.2 If insurance and risk are tightly linked, and if risk is calculable, then we may think that we can understand the insurance business as a kind of applied econometric enterprise.

Work in law and political science has challenged the idea that insurance underwriting and pricing should be based on purely statistical considerations. ${ }^{3}$ Yet even this work has tended to take as given the links between insurance and risk and between risk and calculability. Risk classification undoubtedly is "[t]oo [i]mportant to be [1]eft to the

* William Maul Measey Professor of Law. University of Pennsylvania Law School. Thank you to Jay Feinman and Sean Fitzpatrick for helpful comments.

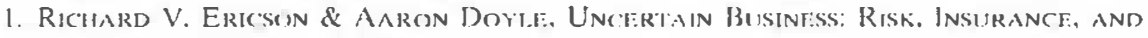
THE LiNITS OF KNOWLEIGG 5 (2()() H).

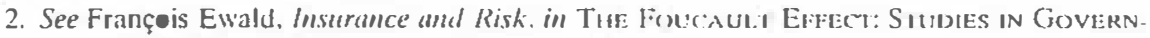
MENTALTrY 197. 201-(2) (Grabam Burcliell el al. eds., 199)1).

3. See Regina dustin. The Insurance Classification Comtrubersy. 131 U. PA. L. REv. 517 (1983): Brian J. Gicnn. The Shifting Rhetoric of Insurance Denial. 34 LaW \& Sox." REv. 779 (2000): Deborals S. Hellman. Is Acunarally Fair Insurance I'ricing Acmully Fuir?: A Case Sunl!' in Insuring Battered Women. 32 Hakv. C.R.C.L. L. RI:v. 355 (1497): Jonathan Simen. The Itlenlogical leffects of Actuarial Practices. 22 LAw \& Sox'y Rl:v. 771 (1488). 
[a]ctuaries," 4 but the substitutes offered are other concepts-equal protection, privacy, and solidarity - that would trump the (imagined) purely statistical analysis only in limited circumstances. Left uninvestigated and therefore not understood by these challenges is the process through which insurance institutions actually transform (or do not transform) uncertainty into risk.

Recent sociological and historical work-most prominently that of Richard Ericson and Aaron Doyle, on the one hand, and Timothy Alborn on the other-has helped to remind us that insurance risks very often are not reliably calculable except in hindsight, at which point the risk has already been transformed into an all-too-measurable loss. ${ }^{5}$ Insurance is an "uncertain business," characterized by competition for premiums that pushes insurers into the unknown. ${ }^{6}$ Even life insurance, the part of the business that manages the oldest and best-understood insurance risk-mortality-operates just beyond the limits of knowledge. ${ }^{7}$ For a recent example, consider the life-settlements market through which hedge funds purchase and hold bundles of life insurance in a strategy to exploit and systematically frustrate life insurers' actuarial assumptions. ${ }^{8}$

This Article takes some preliminary steps in the direction of extending the insights of this sociological and historical work to the liability insurance field. Part II begins with a simple quantitative comparison of U.S. property and liability insurance premiums over the last sixty years, setting the stage to make four points. ${ }^{9}$ First, liability insurance premiums have grown about as much as property insurance premiums over this period, ${ }^{10}$ providing yet another piece of evidence supporting the view that the growth in U.S. liability costs represents an ordinary consequence of a growing economy rather than an unusual or pernicious feature of U.S. culture. ${ }^{11}$ Second, there are systematic variations in the rate of growth in insurance premiums over

4. Leah Wortham, Insurance Classification: Too Important to Be Left to the Actuaries, $19 \mathrm{U}$. Mich. J.L. REFORM 349 (1986).

5. See generally Timothy Alborn, Regulated Lives: Life Insurance and British Soci-

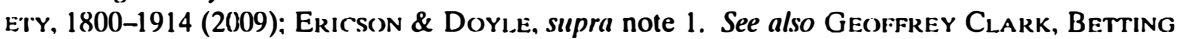
on Lives: The Culture of Life Insurance in England, 1695-1775 (1999); Pat O'Malley, RISK, UNCERTAINTY AND GOVERNMENT (2004).

6. See Ericson \& Doyle, supra note 1, at 47.

7. See id.; see also Alborn, supra note 5, at 9-11, 102-35.

8. See Jenny Anderson, New Exotic Investments Emerging on Wall Street, N.Y. Times, Sept. 6, 2009, at A1.

9. See infra notes $15-22$.

10. See infra notes 17-19.

11. See generally Wili.iam Haltom \& Michael Mc.Cann. Distorting thie Law: Politics, Media, and the Litigation Crisis (2004). 
time corresponding to what is known in the insurance industry as the underwriting cycle. ${ }^{12}$ The cycle is more pronounced in liability insurance than in property insurance, perhaps accounting for the greater popular attention to the uncertainties of liability risks as compared to property risks. Third, the greater variation in liability insurance premiums is almost entirely attributable to the smaller, non-statutorily required lines of insurance: most significantly the various lines of commercial liability insurance. Auto liability and workers' compensation premiums, by contrast, largely vary in tandem with property insurance premiums. Finally, because media coverage of liability and liability insurance increases during the insurance "crisis" stage of the underwriting cycle-when premiums increase sharply-the widely held beliefs in myths about litigation may result, at least in part, from generalizations drawn from a systematically biased set of observations, analogous to the media bias toward big, unusual cases documented by William Haltom and Michael McCann. ${ }^{13}$

Part III moves in a more qualitative, speculative direction by considering liability insurance as a "business that is charged with transforming uncertainty into risk." 14 It discusses how one might explore more systematically in the liability and insurance context the significance of Ericson and Doyle's remarkable conclusion that uncertaintyreducing innovations shift the limits of insurers' knowledge but do not shift insurers' need to operate just beyond those limits. It explores some of the changing terrain of risk and uncertainty on the liability insurance field, closing with the admittedly speculative conclusion that the insurance underwriting cycle might be both a cause and a consequence of liability insurers' efforts to push the liability and insurability frontier.

\section{Comparing Liability and Property Insurance Premiums OVER TIME}

In setting out to compile the aggregate data that would form the empirical backdrop for this Article, I assumed two things that turned out to be wrong. First, I assumed that compiling the data would be easy, because the same statistical service (Best's) has continuously tracked the property casualty insurance industry for over one hundred

12. See Sean M. Fitzpatrick, Fear Is the Key: A Behavioral Guide to Underwriting Cycles, 10 CONN. INS. L.J. 255, 256 (2003).

13. See Haltom \& MCCANn, supra note 11, at 156-59.

14. ERICSON \& DOYLE. supra note 1, at 5; see also infra notes 23-53. 
years. ${ }^{15}$ Second, and more interestingly, I assumed that liability insurance premiums would show much more significant growth than property premiums, particularly in the latter third of the twentieth century.

Like other empirically minded torts teachers, I have followed the tort reform debates closely and, although I have disagreed with the defendants' lobby about the interpretation of the data, ${ }^{16}$ I knew that aggregate liability insurance premiums in the U.S. had grown substantially in real terms over the twentieth century. I had always assumed that this growth significantly outpaced growth in property insurance premiums. Otherwise, why were insurance industry sources so outspoken about rising liability insurance premiums? In most cases, the same insurance groups write liability and property insurance, and I assumed (wrongly, it turns out) that their comparative silence about property insurance premiums meant that those premiums were not increasing as much.

Below, Figure 1 shows that I was wrong about the relationship between property and liability insurance while also showing that, despite some difficulty, it is possible to compile the data. ${ }^{17}$ Figure 1 plots the aggregate liability and property insurance premiums from 1939 to 2008 in constant 2008 dollars for the total U.S. insurance industry, as reported by Best's based on data from the annual reports required to be filed with state insurance departments in the United States (and converted to 2008 dollars using the consumer price index table from the Bureau of Labor Statistics). ${ }^{18}$ The solid line represents total liability insurance premiums; the dashed line represents total property insurance premiums; and the dotted line represents the difference between the two.

15. See Best's, Aggregates and Averages: Property Casualty Edition and predecessor publications.

16. See, e.g., Tom Baker. The Medical Malpractice Mrth (2005); Tom Baker, Herbert Kritzer \& Neil Vidmar, Jackpot Justice and the American Tort System: Thinking Beyond Junk Science (William Mitchell College of Law, Research Paper No. 95. 2008), available at http:/l ssrn.com/abstract=1152306.

17. The difficulty comes from the fact that the data categories have changed several times during the 1939 to 2008 period, reflecting changes in the categories in which insurance regulators have required insurance companies to report their premiums and in which Best's has aggregated that data in its annual publication.

18. See Best's, supra note 15. U.S. Dep't of Labor: Consumer Price Index, ftp://ftp.bls. gov/pub/special.requests/cpi/cpiai.txt (last visited Mar. 31. 2011) (updated monthly). These aggregate premiums likely understate the growth in property and liability losses in the large commercial sector of the U.S. economy, as large corporations have increasingly retained the most predictable and most costly primary layer of exposure, but I am aware of no reason that this trend would have a differential effect on property and liability insurance premiums. 


\section{Figure 1}

Net Premiums Written, U.S. P\&C Industry 1939-2008

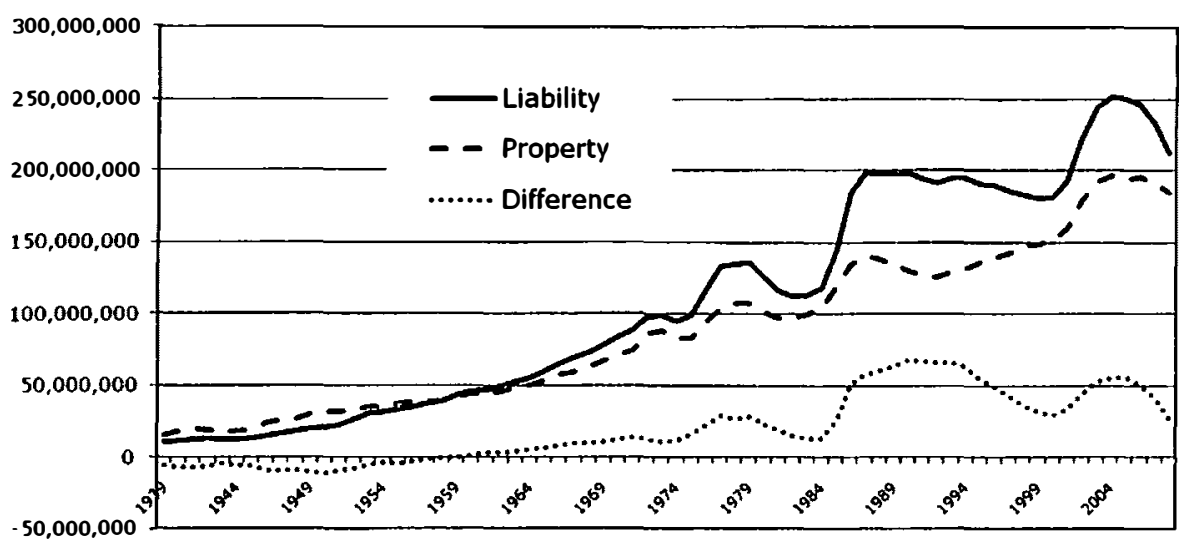

From 1958-the year when total liability premiums first equaled total property insurance premiums - to 2008, property insurance premiums have grown at a real average annual rate of $3.21 \%$ and liability insurance premiums have grown at a real annual average rate of $3.67 \%$. Over that period, property insurance premiums have grown a total of $368 \%$ and liability insurance premiums have grown a total of $436 \%$ in constant 2008 dollars. Over that same period, GDP grew $414 \%$ in real terms, indicating that the property insurance premium growth slightly lagged that of the economy generally and liability insurance slightly outpaced that growth, but the orders of magnitude are very similar. ${ }^{19}$

As the dotted line in Figure 1 reflects, liability insurance premiums have grown at a more variable rate than property insurance premiums. From 1958 to 2008, aggregate liability insurance premiums averaged $124 \%$ of aggregate property insurance premiums, but there was an eleven-year period-from 1986 to 1997 -in which the liability insurance premiums were $145 \%$ of the property insurance premiums. ${ }^{20}$ The difference between the premiums in the two categories of insurance is greatest following the three most significant "hard market" phases of the underwriting cycle that occurred during this period:

19. Author's calculation uses the U.S. Dep'r of Commerce Bureau of Econ. Analysis, GDP TABLES, available at http://www.bea.gov/national/nipaweb/Select Table.asp?Popular $=\mathrm{Y}$ (use Table 1.1.6), and Consumer Price INDEX, supra note 18. Liability insurance premium growth substantially outpaced property insurance premium growth in the early years shown in Figure 1. From 1939 to 1958 , property insurance premiums grew $151 \%$ in real terms while liability insurance premiums grew $265 \%$ in real terms.

20. All calculations are based on Best's data and Consumer Price Index data used as source for Figure 1. 
1976-1977, 1985-1986, and 2002-2003.21 Much of the difference is attributable to rapid growth in liability insurance premiums during just two years: 1985 and 1986 (a 56\% increase in liability insurance premiums over those two years compared to $28 \%$ increase in property insurance premiums). The rest is attributable to differences in growth during $1975-1976$ (34\% for liability and $26 \%$ for property) and $2002-2003$ (27\% for liability and $20 \%$ for property), and to quicker declines in growth in property insurance premiums following each of the three hard market periods.

This difference in the variability of premium growth rates helps explain the popular perception that liability insurance has grown more rapidly than property insurance. During hard market periods, liability insurance premiums in fact do grow more rapidly than property insurance premiums. These are also the periods in which articles about the problems in liability appear most widely in the media. ${ }^{22}$ Thus, although liability and property insurance premiums may be growing at roughly the same rate on average, liability insurance premiums grow more rapidly when people are most likely to pay attention, leading to the facially plausible, but in fact incorrect belief that liability insurance premiums - and therefore the underlying liabilities-generally grow at a rate significantly exceeding the growth in GDP. In other words, the perception that liability and liability insurance premiums have grown disproportionately in relation to the underlying economy represents a generalization from a biased set of observations.

Below, Figure 2 presents a breakdown of the liability insurance premiums over time by category of insurance. Figure 2 reflects a reality that is often forgotten: at the aggregate level, the liability insurance market is dominated by the legally mandated forms of liability insurance-auto liability and workers' compensation. Automobile liability insurance premiums account for more than half of the total in all but a few years during this period. Only in very recent years have all of the other kinds of liability insurance put together equaled the workers' compensation share of liability insurance premiums. Moreover, the slight decline in the share of workers' compensation insurance premiums reflects slower growth in workers' compensation insurance premiums rather than particularly rapid growth in the other non-auto

21. See Scott E. Harrington, Tort Liability, Insurance Rates, and the Insurance Cycle, in Brookings-Wharton Paipers on Financial Services 97, 97 (Robert E. Litan \& Richard Herring eds., 2004).

22. See Tom Baker, Medical Malpractice and the Insurance Underwriting Cycle, 54 DEPAuL L. REv. 393, 431-33 (2005) (reporting results of content analysis of news files relating to medical malpractice). Cf. HALtom \& McCANN, supra note 11, at 147-82 (discussing the importance of the media to perceptions about tort law). 
lines of liability insurance. Despite all the attention to medical malpractice and products liability in the media and the academic literature, medical malpractice insurance premiums represent a tiny fraction of the total; and the products liability insurance premium line is barely visible at the bottom of the chart.

Figure 2

Liability Insurance Net Premiums Written, 1939-2008 2008 Dollars (IN THOUSANDS)

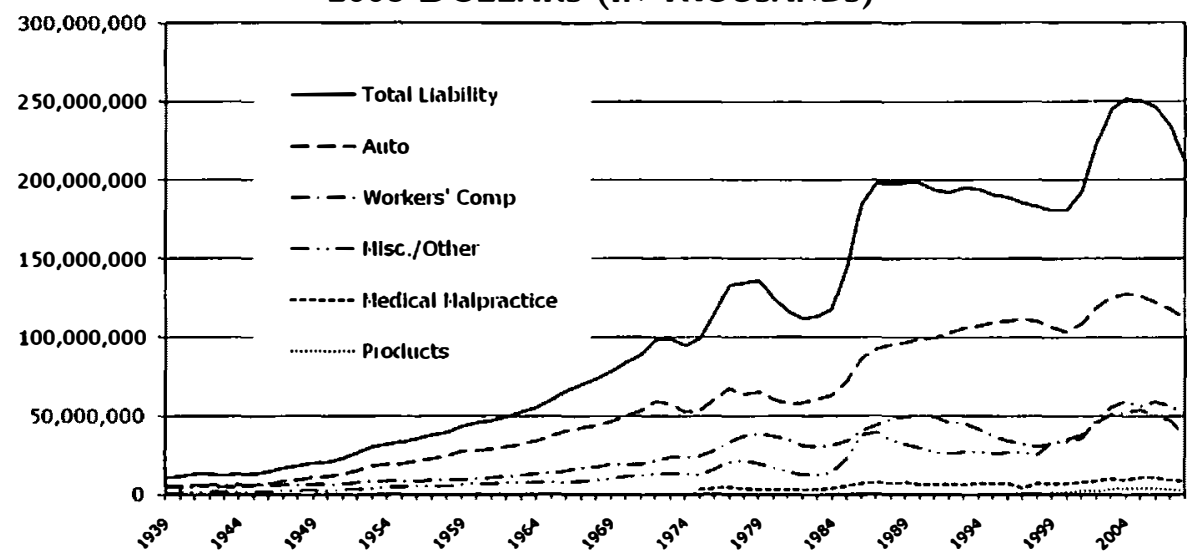

Thinking about Figures 1 and 2 together raises a question about what portions of the liability insurance market are driving the difference in the variability of the liability and property premiums over time. Figure 1 shows that liability insurance premiums are more variable than property insurance premiums. Figure 2 suggests that the lines of insurance that are not the legally mandated forms of liability insurance have grown more significantly than those traditional lines (auto and workers' compensation), but Figure 2 does not allow for easy comparisons in the rates of growth. Figure 3, below, does just that. Figure 3 shows the annual real growth in property insurance premiums (the dotted line), the statutorily mandated liability insurance lines of auto and workers' compensation (the dashed line), and all of the other lines of liability insurance (the solid line). As Figure 3 shows, the growth in automobile and workers' compensation lines has closely tracked that of property insurance since the 1950s. The big difference lies in the other lines of liability insurance, suggesting that there are greater year-to-year uncertainties in those other lines of liability insurance than in either automobile liability or workers' compensation insurance. 
Figure 3

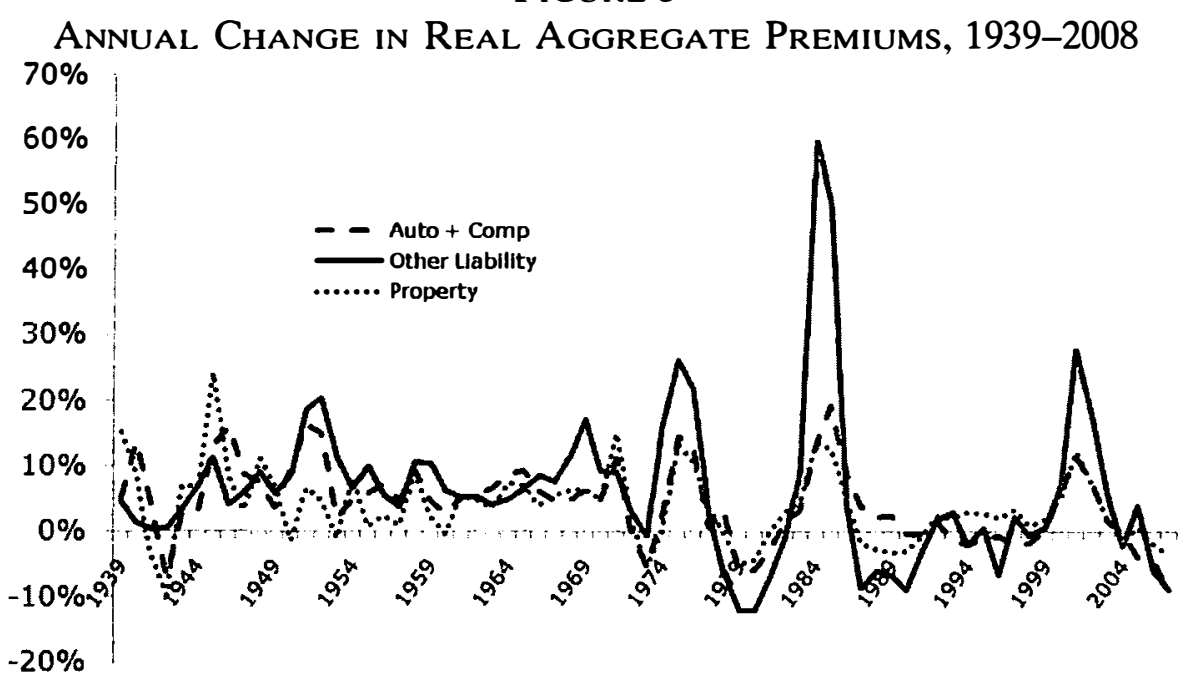

III. Transforming Uncertainty into Risk?

Summarizing the discussion thus far, what we see is that aggregate U.S. property and liability insurance premiums have grown at roughly the same rate, on average, since the middle of the twentieth century, but the growth in liability insurance premiums varies over time more significantly than the growth in property insurance premiums. The long term total growth in liability insurance premiums is largely attributable to automobile liability insurance, with the premiums for all non-auto liability insurance exceeding the premiums for workers' compensation insurance only in the last ten years; this is apparently a result of decline in the growth of workers' compensation insurance rather than a significant increase in the growth of these other kinds of insurance. Finally, developments in those other kinds of liability insurance account for most of the greater variation in liability insurance premiums as compared to property insurance.

If Ericson and Doyle's generalizations about risk and uncertainty hold true in the liability insurance market, then these already variable aggregate results should be masking even more turmoil in the operation of the liability insurance business. There are good reasons to believe that Ericson and Doyle's generalizations do hold true in this context. Ericson and Doyle investigated three sectors of the insurance industry: life insurance, disability insurance, and property insurance. ${ }^{23}$ Notwithstanding the significant differences among these sectors-dif- 
ferent kinds of insured risks and different approaches to managing those risks-the researchers found a common pattern of competition pushing organizations just beyond the limits of knowledge. ${ }^{24}$ To believe that this pattern would not hold in the liability insurance context, we would need to have some reason to conclude that liability insurance risks are more calculable than life, disability, or property insurance risks.

Yet there are good reasons to believe that liability insurance risks may be less calculable than these other risks. The forms of insurance that Ericson and Doyle investigated are loss-based, meaning that they provide financial protection for the designated harm (death, disability, or property damage) without regard to how the harm took place. Pricing these kinds of insurance requires estimating the rate and cost of the insured harms. By contrast, liability insurance provides financial protection only when the harm can be attributed to a liabilitycreating act such as the breach of the standard of reasonable care orin the workers' compensation context-an injury arising out of work. This means that the uncertainties of liability insurance include not only developments in the rate and cost of insured harms but also developments in the standard of care and other aspects of liability. ${ }^{2.5}$ Uncertainties about these latter developments add an additional layer of uncertainty to the uncertainties about the underlying injuries and damage. The greater variation between property and liability insurance premiums at the aggregate level, as described in Part II, provides some support for this conclusion.

Nevertheless, even if liability-related risks are only as uncertain as those addressed by disability, life, and property insurance, that would leave more than enough room for the dynamic that Ericson and Doyle described: namely, that uncertainty-reducing innovations shift the limits of knowledge but not insurers' need to operate just beyond those limits. In the remainder of this Part, I will offer some admittedly impressionistic suggestions of some of the ways that this dynamic plays out in the liability insurance context.

\section{A. Transforming Uncertainty into Risk}

Based on observation and study of the liability insurance market, my sense is that three key developments have improved liability insurers' ability to predict liability risks. This sense represents informed

24. See id. at 22-23.

25. See Tom Baker, Insuring Liability Risks, 29 Gfansva PApers on RIsk ANI Ins. 128, 130-31 (2004). 
intuition, without systematic empirical support. Thus, the following should be regarded as hypotheses, not proof: (1) advances in data gathering and analysis have led to a quantitative revolution in the tracking and valuation of routine claims, especially in the automobile liability context, resulting in more accurate forecasts of both the frequency and severity of insured liability losses; (2) because the liability insurance policy limits purchased by individuals have not kept pace with inflation, once again especially for automobile liability, an increasing percentage of claims are capped at the policy limit, in effect truncating the right tail of the severity distribution (i.e., the high severity claims that happen less frequently); and (3) insurers have shifted an increasing proportion of their professional and commercial liability risks into a kind of insurance contract that poses less of the difficult-to-evaluate "long tail" liability risk than the contracts of the past. The paragraphs that follow describe each of these hypotheses in turn.

\section{The Quant Revolution}

Although still very much a work in progress, the quant revolution has significantly changed the valuation of routine accident claims, especially in the automobile liability context. The automobile insurance adjusters from the 1960s, as profiled in H. Lawrence Ross's Settled Out of Court, used their intuition and experience to craft settlement offers. ${ }^{26}$ Today, automobile insurance adjusters use claims-valuation software that takes the injury and demographic information and produces a range of permissible settlement offers. To my knowledge, there are no publications reporting the results of horse races between the quantitative models and experienced adjusters, but my informed impression is that the automobile insurance industry has completely shifted to data-driven adjusting for routine claims and relies heavily on claims-valuation software even when adjusting serious, non-routine claims. This shift strongly supports the view-expressed forcefully in Ian Ayres' Super Crunchers-that "intuition and experience are evolving to interact with data-based decision making."27

The insurance industry has long had massive amounts of data. Since the 1990s, the industry has been working on making that data accessible for (proprietary) analysis, for example by putting underwriting and claims data on the same platform, with the result that the

26. See generally H. Laurence Ross, Settled out of Court: The Social Process of Insurance Claims Adjustment (1980).

27. Ian Ayres, Super Crunchers: Why Thinking-by-Numbers Is the New Way to Be SMART 16-17 (2007). 
"truly massive" datasets that Ian Ayres describes are now available within all of the major automobile insurance companies. ${ }^{28}$ Other lines of insurance may have lagged behind, ${ }^{29}$ but the clear trend in the liability insurance industry is to extend the quant revolution into other lines and into more severe claims. This trend points toward the realization of the "actuarial" approach to liability insurance that many lawyers and law professors probably thought was already more fully embodied in insurance practice than was actually the case. ${ }^{30}$

\section{The Increasingly Binding Nature of Liability Limits}

Absent the poor claims-handling that leads to liability for "bad faith," an insurance company's liability for any given claim is capped at the dollar limit of the applicable insurance policy. ${ }^{31}$ No matter how serious the injury or how wrongful the defendant's conduct, the liability insurance policy limit is the most that a liability insurance company is contractually obligated to pay as long as the claim is handled properly. Because plaintiffs almost never collect "real money" from "real people," even a claim that involves damages that significantly exceed the liability insurance policy limit will ordinarily be settled for no more than the available insurance amount. ${ }^{32}$ Indeed, the more that the value of the case exceeds the policy limit, the more quickly that the case will be settled for that policy limit because of the well-established insurance law "duty to settle." 33 This dynamic is well established and well appreciated by informed observers of the liability and insurance universe. ${ }^{34}$

28. Author's personal knowledge based on use of confidential, proprietary insurance company data as reported in Albert Yoon \& Tom Baker, Offer-of-Judgment Rules and Civil Litigation: An Empirical Study of Automobile Insurance Litigation in the East, 59 VAND. L. Rev. 155 (2006).

29. See, e.g., Charles Silver \& Kathryn Zeiler, Presentation to Law and Society Association: Medical Malpractice Reserving Practices (2009) (powerpoint slides on file with author) (reporting surprising and persistent inaccuracies in medical malpractice insurance reserving revealed in the Texas Insurance Department Closed Claim database).

30. Cf. Simon, supra note 3 , at 786 (describing the critique of actuarial practices in which the individual is "the sum of the many roles he plays as a result of being a member of many status groups").

31. See generally Kent D. Syverud, The Duty to Settle, 76 VA. L. Rev. 1113 (1990).

32. Tom Baker, Blood Money, New Money, and the Moral Economy of Tort Law in Action, 35 LAw \& Soc'y Rev. 275, 276 (2001).

33. Syverud, supra note 31 , at 1116.

34. See generally Baker, supra note 32, at 275. See also Bernard Black, Brian Cheffins \& Michael Klausner, Outside Director Liability, 58 Stan. L. Rev. 1055 (2006) (explaining this dynamic in the securities class action and directors' and officers' liability insurance contexts); Kathryn Zeiler et al., Physicians' Insurance Limits and Malpractice Payments: Evidence from Texas Closed Claims, 1990-2003, 36 J. Legal Stud. S9 (2007). 
Less well appreciated, however, is the aggregate consequence when liability insurance premiums fail to keep up with inflation. As Kenneth Abraham explained in The Liability Century, the mandatory minimum automobile insurance policy limits have significantly lagged behind inflation, with the result that tort damages as determined by the law on the books are increasingly likely to exceed the available automobile insurance. ${ }^{35}$ Because the insurance companies' obligation to pay is capped at the policy limit, and because "blood money" is so rarely paid, this trend means that the damages awarded by tort law in action increasingly are simply the liability limit of the defendants' automobile liability insurance policy, sometimes supplemented by the plaintiffs' underinsured motorist coverage. Research using the Texas Department of Insurance medical malpractice claims database suggests that the same phenomenon may be occurring with respect to medical malpractice claims, though with less impact on liability insurance overall because of the relatively small size of the medical liability insurance market. ${ }^{36}$

\section{The Changing Nature of Liability Insurance Contracts}

The two developments just discussed are most significant for automobile liability insurance. This third development affects commercial liability. Beginning with medical malpractice insurance in the 1970s, the liability insurance industry has gradually been shifting its "long tail" business (i.e., liability risks in which there is a long lag between the wrongful conduct and the eventual lawsuit) into liability insurance contracts that provide coverage on a claims-made basis.

Traditionally, liability insurance provided coverage on an accident basis, meaning that the policy covered accidents that took place during the policy period. ${ }^{37}$ This is still the case for automobile liability insurance. In the 1960s, the insurance industry shifted toward providing coverage on an occurrence basis, which extended the original concept of accident to incorporate events that took place gradually, potentially over a long period of time..$^{38}$ This approach led to massive exposures for asbestos and environmental injuries in the commercial context, and also for birth- and childhood-related conditions in the medical malpractice context.

35. See Kenneti S. Aibailam, The Liability Centiliky: Insurance and Tori Law from The Progikessive Era To 9/11, at 101 (2008).

36. See Zeiler et al., supra note 34 , at $\mathbf{S 9}$.

37. See Tom Baker. Insuranc.e Law and Poi.icy 355 (2d ed. 2008).

38. See id. 
In response, the insurance industry shifted in the 1970s and 1980s to providing coverage on a claims-made basis in professional liability insurance and somewhat later-more gradually, and less completely-in the product and environmental liability context. ${ }^{39}$ A claims-made policy provides coverage for claims that are first made during the policy period. ${ }^{40}$ The claims-made form of coverage provides greater predictability to insurers for two reasons. First, the policy is more likely to be sold close in time to when the claim is paid, thereby allowing the insurer to incorporate more recent information about the frequency and severity of claims into the price for the coverage. Second, because a claim can be first made only once, there is less likelihood that policies from multiple years will be triggered by a claim or a set of related claims (such as a mass tort), thereby capping the insurer's exposure at the limit of a single policy (in marked contrast to the situation under an occurrence policy).

\section{B. Transforming Risk into Uncertainty}

At the same time that these developments transformed uncertainty into risk, other developments pushed in the opposite direction. In the personal lines liability insurance context, which mostly means automobile liability insurance, the two most important developments were the "arms race" in risk segmentation and the politics of automobile insurance pricing. The commercial lines context is more complicated because commercial liability risks evolve with the underlying economy. One important and easy-to-explain commercial lines development concerns corporations' increased willingness to retain risk, with the result that commercial liability insurance increasingly involves the right tail risk, precisely the opposite of personal automobile liability insurance. The sections that follow explain each of these.

\section{The Arms Race in Automobile Risk Segmentation and Distribution}

Of all of the forms of insurance investigated by Ericson and Doyle, personal automobile liability insurance is most like life insurance, at least in terms of the dynamics of uncertainty and risk. Like mortality, automobile liability risk is well understood in the aggregate. And, because of the quant revolution in claims evaluation and the increasingly binding nature of automobile liability insurance limits, the loss associ-

39. See id. at 388; Bob Works, Excusing Nonoccurrence of Insurance Policy Conditions in Order to Avoid Disproportionate Forfeiture: Claims-Made Formats as a Test Case, 5 Conn. Ins. L.J. 505, 508-09 (1998).

40. See generally Works, supra note 39 , at 505 . 
ated with any given automobile liability claim is almost as determinable as the loss associated with any given death claim. So, as with life insurance, the competitive action lies in innovations in the slicing and dicing of the insured population and in product distribution. (Unlike life insurance, competition in the auto insurance industry rarely involves innovations in product development because of strict regulatory controls over the automobile insurance policy.) ${ }^{41}$ A company that develops a new way to identify the low risk-segment of an existing risk category reaps a double benefit: lowering its own average claims cost in that segment while increasing the average claims costs of its competitors. Similarly, a company that develops a new way to distribute its product - through a new affinity relationship or a new direct mail or television campaign, for example-simultaneously gets new customers and disrupts the business patterns of its competition.

The result is an evolving set of risk classifications that limits the ability of insurers to price on the basis of their own claims history (because they did not collect data on the basis of these classifications in the past) and an evolving customer mix. As with life insurance, the aggregate risk is a predictable, slowly moving mass, but the dynamics of the market mean that individual insurers operate at the edge-or just beyond the edge-of their knowledge. The quant revolution changes the location of that edge, not the competitive pressure to operate just beyond it.

\section{The Politics of Automobile Insurance Pricing}

The politics of automobile insurance pricing inserts an additional uncertainty into the automobile liability market that does not exist in the life insurance market. With the transition of the Massachusetts automobile insurance market to a kind of managed competition, ${ }^{42}$ there are no longer any state insurance departments that set rates. But all state insurance departments retain some authority over changes in rates. Given inflation and the fact that insurance rates are set in nominal dollar terms, all insurance companies eventually need to raise their automobile insurance rates. In most cases, insurance regulators do not object. But sometimes they do object. That is a source of uncertainty.

41. The recent "accident forgiveness" programs represent a partial exception to this rule. Strictly speaking. accident forgiveness programs represent a change in pricing, not in product design, but the programs are marketed as a feature that is analogous to a change in design.

42. See, e.g., Phil Gusman. Mass. Auto Insurers Hail Improved Market Since Reforms, Despite Criticism by AG. Nat'l Underwriter, Apr. 19, 2010, at 14. 


\section{Commercial Liability Insurance: $A$ Window on the Underlying Economy}

It is difficult to make useful generalizations about a business that is as diverse as commercial liability insurance, a field that in its broadest definition includes professional liability insurance, many specialized forms of liability insurance, and the more commonly understood general liability insurance. Liability insurance tends to extend over time to match liability itself (with lags and with exceptions), and thus developments in liability law, both on the books and in action, represent a source of uncertainty for liability insurers. ${ }^{43}$ Almost all changes in the economy produce at least some change in the mix of liabilities assumed by liability insurers, and thus the creative destruction of a capitalist economy represents another source of uncertainty for liability insurers. ${ }^{44}$ The shift from manufacturing to services, the globalization of the supply chain, and the expansion of the high tech and health care sectors of the economy, among many other developments, all have consequences for liability insurers if only by reducing the predictive value of historical information about the frequency and severity of claims.

\section{Corporations Retain More Risk}

There is one major cross-cutting development in the commercial lines marketplace that is worth singling out: businesses of all kinds are retaining greater levels of risk, as represented by the rising deductibles and self-insured retentions. Businesses, unlike individuals, have learned what may be the most important lesson of risk management theory and research: because of the inevitable loading costs of insurance, it makes no sense to buy insurance for losses that are small in relation to easily available assets. ${ }^{45}$ Since at least the 1980s, businesses have preferred to buy liability insurance policies with higher deductibles and higher limits. ${ }^{46}$ The aggregate result is to remove the most predictable liabilities from the liability insurance pool, leaving insurers dependent on providing protection against relatively extreme liabilities. Replacing the premium lost when a corporation raises its workers compensation or liability insurance deductible by $\$ 1$ million requires selling a lot of excess insurance, because excess coverage is

43. Baker, supra note 25 , at 133.

44. See generally Joseph A. Schumpeter, Capitalism, Socialism, and Democracy (1942).

45. See, e.g., Scott E. Harrington \& Gregory R. Niehaus, Risk Management and In. SURANCE 489, 505 ( $2 \mathrm{~d}$ ed. 2004) (explaining reasons for retaining risk).

46. Id. at 527 (reporting that "medium to large business insurance policies often include relatively large deductibles or self insured retentions"). 
less expensive than primary insurance on a per-dollar-of-coverage basis. As a result, commercial liability insurance has become increasingly focused on the right tail of the liability claim distribution, which is characterized by larger, less frequent losses, especially for large organizations. Liability insurers believe that, in the jargon of the business press, this is a "fat tail," meaning that commercial liability losses do not follow a normal distribution. ${ }^{47}$ As the quant revolution enables large organizations to transform their liability uncertainties into risk, the organizations will retain more of that risk, and they will endeavor to shift the remaining uncertainties to their liability insurers.

\section{The Insurance Underwriting Cycle}

As reflected most clearly in Figures 1 and 3, the property casualty insurance industry goes through a business cycle that is characterized by long periods of relatively stable insurance prices, often slowly declining in real terms, and short periods of rapid price increases. There is an extensive literature on this cycle-including a contribution by me-and perhaps the one thing upon which there is universal agreement is that no one fully understands what drives the cycle. ${ }^{48}$ Not surprisingly, the cycle is a major preoccupation in the industry. Industry trade publications regularly report on what industry leaders and analysts think about where the industry is in the cycle, and predictions of this sort can have very significant strategic implications for companies. ${ }^{49}$

During a "hard market," prices significantly exceed costs and insurers can implement new restrictions on coverage and underwriting. During a "soft market," prices gradually decline in real terms and insurers gradually abandon coverage and underwriting restrictions. By the end of the soft market, almost all insurers are almost certainly selling insurance below cost, retaining market share in the hope of making money once the market turns hard. Warren Buffet, whose most significant holdings are property casualty insurance companies,

47. See Roger Gay, Pricing Risk When Distributions Are Fat Tailed, 4lA J. Applied Probability 157, 157-58 (2004) (reporting that generally insurance claims are fat tailed).

48. See Baker, supra note 22, at 401-22 (summarizing literature). For recent contributions. see Ursina B. Meier, Multi-National Underwriting Cycles in Property-Liability Insurance: Part I Some Theory and Empirical Results, 7 J. OF RISK FIN. 64 (2006); Julien Trufin, Hansjörg AIbrecher \& Michel Denuit, Impact of Underwriting Cycles on the Solvency of an Insurance Company, 13 N. Am. Actunial J. 385 (2009).

49. See, e.g., David Gambrill, What Happened to the Hard Market?. Canadian Under. WrITER, Oct. 2009, at 78, 78; Barrett Hubbard, The Inevitability of Market Cycles. CANAIIAN Underwriter, Sept. 2007, at 34. 35; Al Slavin, What's Next?: Surplus Lines Writers Look to New Products and Specialized Underwriting to Extend Business, Brss's Rev., Apr. 2010, at 28. 29. 
has famously advocated paying underwriters not to write insurance during severe soft markets, because the company will almost certainly lose money on the book of insurance sold at that time. ${ }^{50}$ The problem is, of course, that no one really knows when the cycle reaches the point at which liability insurance costs exceed prices-because the costs will not be known for sure until the future-and no one really knows the value of keeping market share during the soft market. ${ }^{51}$

The underwriting cycle contributes to the uncertainty in liability insurance in a variety of ways. The periodic relaxation and restriction of underwriting and coverage practices reduce the predictive value of each insurance company's claims history, because the mix of risks insured does not remain consistent over time. Keeping market share during a soft market involves heading off into the unknown. By definition, the relaxation of underwriting and coverage restrictions means selling insurance against risks that the insurer had not been willing to insure in the prior period. Among reinsurers, a continuation of a soft market means that the reinsurer needs to be easier for insurers to deal with and that means relaxing-and at some point abandoning-detailed reporting requirements at the individual insured and claim level. ${ }^{52}$ The result is that reinsurers do not have continuous individual and claim level data of the sort that would allow them to control for the changing mix of business among the insurance companies that they reinsure. When the hard market arrives, insurance companies raise prices and jettison some of their worst risks, almost certainly writing profitable business-but just how profitable remains uncertain, as does the amount of time before enough new capital enters the insurance market for the underwriting cycle to turn once again. ${ }^{53}$ In that sense, we can regard the liability insurance underwriting cycle as both a cause and a consequence of liability insurers' efforts to push the insurability frontier.

50. Letter from Warren Buffett, Chairman, Bd. of Dirs. of Berkshire Hathaway Inc., to Shareholders 6-8 (Feb. 28, 20()5), available at http://www.berkshirehathaway.com/letters/2()()4ltr.pdf.

51. See Matthew Dolan, Repeating the Sins of Market Cycles, Insıcirrs, Oct. 2003, at 1 (on file with author) (article by the president of a liability insurance company reporting "our industry realizes the 'right priced' environment only momentarily during the shift from the hard to the soft market" and arguing "the cyclicality of this business will be perpetuated, and capacity will engage in wild and irrational movements over the price/quality line, unless carriers" adopt a variety of measures that are unlikely to be adopted given competitive pressures).

52. Author's confidential, personal communication with reinsurance underwriters as part of the field research reported in Tom Baker \& Sean J. Griffiti, Ensurinci Corporate Misconisuct: How Liability InsUrance Undermines SiIAREholder Liticiation (2010).

53. See generally Baker, supra note 22, at 393: Dolan, supra note 51, at 1: Fitzpatrick, supra note 12 , at 255 . 


\section{Conclusion}

These competitive consequences of the liability insurance underwriting cycle resonate well with the dynamic of Ericson and Doyle's Uncertain Business. ${ }^{54}$ Even as liability insurers develop technologies that would better predict the losses of a stable risk pool, competition reshapes companies' risk pools, so that they operate just beyond the edge of their knowledge. This dynamic helps explain how the liability insurance field can feel out of control even to expert participants. "Fear is the key," in the words of insurance industry leader Sean Fitzpatrick. $^{55}$ Those feelings put expert passion behind the popular beliefs that have fueled the restrictive tort reform movement. Taking the long view, liability and liability insurance premiums have grown at about the same rate as the U.S. economy. But few people live their lives consistently taking this long view, and the long view may not even be adaptive in the competitive arena.

54. See generally ERicson \& Doyi.e, supra note 1.

55. See Fitzpatrick, supra note 12, at 255-56 (quoting title of Alistair MacLean's novel. FraR IS THE KEY). 